УДК 621.3

DOI 10.36910/6775-2313-5352-2020-17-20

Федорчук-Мороз В.І., канд. техн. наук, доц., Вісин О.О., канд. істор. наук, доц.,

Ліщук М.Є., канд. с.-г. наук, доц.

Луцький національний технічний університет

\title{
ПРАВИЛА БЕЗПЕЧНОГО ЕЛЕКТРОМОНТАЖУ
}

Анотація. Правила безпечного виконання електромонтажних робіт завжди було актуальним, адже безпосередньо стосується збереженню життя та здоров'я прачівників. В статті розкрите питання умов праиі електромонтажних робіт, їx безпечне проведення. Особлива увага приділена питанням успішного та якісного виконання електромонтажних робіт, а також чинникам які призводять до травм та ушкоджень. Проведено аналіз виконання робіт на висоті згідно з яким висунуті рекомендачії роботодавию для врахування наявних небезпечних та шкідливих виробничих чинників. Для більшого розуміння небезпечності електромонтажних робіт було визначено ризики їх утворення, тобто моделювання прочесів формування та виникнення травмонебезпечних і аварійних ситуацій.

Ключові слова. електромонтажні роботи, безпечність, травматизм, правила охорони праиі, небезпечні та шкідливі чинники.

Постановка проблеми. Збереження здоров'я і життя працівників в процесі трудової діяльності являється одним 3 найважливіших завдань на будь-якому підприємстві незалежно від форм власності, чи виду діяльності. Тому основним принципом державної політики в галузі охорони праці являється пріоритет життя і здоров'я працівників і повної відповідальності роботодавців за створення належних, безпечних і здорових умов праці.

Згідно законодавства України про охорону праці керівники, роботодавці та спеціалісти підприємства зобов'язані постійно підвищувати рівень промислової безпеки шляхом забезпечення суцільного технічного контролю та впровадження сучасних технологій 3 метою вдосконалення безпечних методів праці та усунення шкідливих факторів виробництва.

Електромонтажні роботи відноситься до категорії важких та небезпечних робіт, адже це роботи на висоті, роботи з електрообладнанням, які потребують значної точності та увагу.

Аналіз останніх досліджень і публікацій. Питання охорони праці та шляхи їх впровадження в нашій державі розглядалось багатьма дослідниками, адже це є актуальним i дієвим. Такі науковці як: Халімовський М.О. , Кундієва Ю.І., Любимова В.С., Гогіташвілі Г.Г., Ткачук К.Н. та інші - чимало свої праць присвятили питанню стану та перспектив розвитку охорони праці підприємств. Нажаль сьогодні економіка України втрачає до 4 \% ВВП за рахунок виплат на пільги та компенсації постраждалим від нещасних випадків, чи профзахворювань. Натомість держава повинна спрямовувати кошти на профілактику виробничого травматизму та профзахворювань, на нове, сучасне, безпечне обладнання, на нормалізацію умов праці. Закордонний досвід показує, що витрати на дотримання законодавства з охорони праці і покращення умов праці завжди менші ніж витрати пов'язані $з$ ліквідацією наслідків. Нажаль усвідомлення того, що це є фактор соціально-економічного розвитку суспільства до нас ще не дійшло.

Формування цілей статті. Проаналізувати та провести комплексне дослідження питань безпеки проведення робіт при електромонтажі, а також дослідити небезпечні та шкідливі чинники при виконанні таких робіт.

Результати досліджень. Порушення режимів роботи працівників, механізмів та приладів, які використовуються в технологічних процесах, електрифіковане устаткування, інструмент і електропроводка; ручні роботи, що викликають фізичні і нервово-психічні навантаження та ін. - все це найчастіші основними джерелами шкідливих та небезпечних факторів на більшості підприємствах. сучасний техномодернізований світ широко використовує різноманітні технології та види робіт, левова частка яких припадає на електромонтажні роботи.

Тому й травматизм під час їх виконання у нашій державі є досить високими і страждають зазвичай висококваліфіковані працівники (статистика показує данні - 65\% нещасних випадків), які мають і стаж роботи і високу кваліфікацію. Це пов'язане з тим, що всі роботи пов'язані 3 
монтажем обладнання однозначно відносяться до важких робіт і зазвичай виконуються в умовах де є небезпечні та шкідливі виробничі фактори.

Проаналізувавши визначення електромонтажних робіт, вважаємо найбільш суттєвим та змістовним наступне формулювання: «електромонтажні роботи - це поняття, яке включає в себе комплекс заходів щодо розробки проекту, організації, а також проведенню монтажу (встановлення) різноманітного електрообладнання у приміщеннях і на відкритому повітрі, в тому числі і електропроводки» [1]. Враховуючи високий рівень травматизму, вважаємо, що такі роботи вимагають значного професійного досвіду, достатніх теоретичних знань і відповідної освіти.

Для успішного та якісного виконання електромонтажних робіт необхідно чітко продумати їх організацію. Перша умова виконання роботи - це складання детального плану розміщення електровузлів. Наявність проекту виконання електромонтажних робіт облегшить роботу та потягне за собою підвищення продуктивності праці, зниження собівартості і т.д.

Аналіз електромонтажних робіт свідчить: «під час монтажу технічно складного електроустаткування великих об'єктів для кращої організації робіт застосовують так звану зональну систему. Для цього, виходячи 3 обсягу чи характеру передбачуваних електромонтажних робіт, весь об'єкт розбивають на монтажні зони. В кожній зоні виконують певний комплекс робіт, який характеризується їх однорідністю або технологічною завершеністю» [1]. Так звані «електромонтажні зони» повинні бути поділені за безпекою ведення електромонтажних робіт, економічною доцільністю та можливістю гнучкого виробництва.

За словами дослідників: «підвищенню ефективності монтажу (високій продуктивності праці) сприяють раціональні технологічні операції і послідовність їх виконання. 3 цієї точки зору слід визнати найбільш раціональним ведення монтажу в одну стадію. Такий монтаж починають після закінчення будівельних робіт, у процесі виробництва яких виконувалось встановлення закладних деталей, утворення отворів, борозен, проходи через стіни і перекриття, роботи по підготовці траси. При одностадійному монтажі послідовно по ділянках траси на кожній із них повністю виконують всі монтажні операції, починаючи 3 підготовки місць кріплення опорних конструкцій. Потім встановлюють конструкції, прокладають і закріплюють струмопроводи і після цього випробовують їх. Така організація робіт дає змогу пройти «трасу робіт» за один раз, повністю виконавши весь монтажний процес» [1].

Отже ігнорування елементарних правил охорони праці однозначно призведе до отримання травми і навіть до нещасних випадків. Провівши аналіз травм при проведенні електромонтажних робіт необхідно виділити найпоширеніші: удари, пошкодження тканин обертовими деталями приладів; електроопіки в результаті прямого або дугового контакту тіла 3 джерелом струму; травми слизової оболонки очей від попадання пилу і дрібної стружки під час свердління; проблеми з легенями при попаданні в них пилу від деяких композитних матеріалів (МДФ, склопластики і т.д.)

Значна кількість монтажних робіт відноситься до монтажу вторинних мереж і згідно законодавства до таких робіт допускаються особи старше 18 років, які пройшли:

«- медичний попередній огляд та визнані придатними виконувати електромонтажні роботи на висоті;

- навчання в закладах освіти для виконання робіт з підвищеною небезпекою (у професійно-технічних училищах, навчально-курсових комбінатах, центрах підготовки та перепідготовки робітничих кадрів, в організаціях) за затвердженою програмою;

- навчання та перевірку знань з електробезпеки;

- спеціальне навчання та атестацію з питань пожежної безпеки;

- вступний інструктаж з охорони праці;

- первинний інструктаж безпосередньо на робочому місці» [2].

(C) Федорчук-Мороз В.І., канд. техн. наук, доц., Вісин О.О., канд. істор. наук, доц., Ліщук М.Є. канд. с.-г. наук, доц. 
Насамперед для допуску до виконання електромонтажних робіт працівнику необхідно обов'язково проходити попередній (періодичний) медичний огляди, який передбачений наказом МО3 України від 21.05.2007 № 246 [3]. Адже зберегти здоров'я працівника та попередити розвиток ускладнень та погіршень стану здоров'я можна лише під час медогляду. Своєчасне виявлення ознак будь-якого захворювання захистить роботодавця і працівників від нещасного випадку [3].

В Порядку проведення медичних оглядів чітко написано: «При працевлаштуванні робітника роботодавець на підставі Акта визначення категорій працівників, які підлягають попередньому (періодичним) медичному огляду, складеного фахівцем відділу з питань гігієни праці територіального Управління Держпраці, видає направлення, передбачене додатком 3 до п. 2.4 Порядку, та направляє до закладу охорони здоров'я, з яким укладено договір. Далі комісією закладу охорони здоров'я, у складі якої обов'язково має бути лікар із відповідною підготовкою з профпатології, проводиться медичний огляд працівника» [3]. Щодо лікарів при такому огляді то це: терапевт, невропатолог, оториноларинголог, офтальмолог. Такий перелік лікарів в першу чергу зумовлений виявлення хвороб не сумісних 3 виконанням електромонтажних робіт. Окрім вищеперерахованих лікарів, для виконання робіт на висоті необхідний ще обов'язковий огляд хірурга. «Склад лікарської комісії, яка здійснює медичний огляд, може доповнюватися іншими фаховими лікарями. При попередньому медичному огляді обов'язково проводиться рентгенографія органів грудної клітки у прямій проекції. Після проведення всіх необхідних досліджень та оглядів комісія враховує перелік загальних медичних протипоказань до роботи зі шкідливими та небезпечними факторами виробничого середовища і трудового процесу, а також додаткові протипоказання відповідно до конкретних умов праці, що наведені в додатку 5 до Порядку, та визначає придатність працівника до роботи» [3].

Кожен працівник перед виконанням роботи на об'єкті повинен чітко знати всі умови праці та особливості підприємства-замовника.

Перед початком роботи монтажники повинні обов'язково пройти первинний інструктаж про безпечне виконання робіт, причому питання повинні стосуватись не тільки основної професії, а й суміжних, а також ознайомлення 3 правилами надання першої домедичної допомоги.

Згідно законодавчих норм забороняється допускати монтажників до виконання обов'язків 3 монтажу вторинних мереж, які мають простудні і хронічні захворювання верхніх дихальних шляхів [2]. Нажаль, цю вимогу досить часто не беруть до уваги, нехтуючи простудними чи хронічними захворюваннями дихальних шляхів, і як результат наражання працівників на небезпеку, на помилковість дій, і як результат травма, нещасний випадок і т.д.

Всі роботи на висоті (при підйомі над поверхнею вище ніж 1,3 м) потрібно виконувати тільки з риштувань або помостів [4].

Перед початком роботи кожен працівник отримує спецодяг, спецвзуття та інші засоби індивідуального захисту. Одержані пристрої має перевірити справність та комплектність.

Проаналізувавши вимоги безпеки під час виконання вторинних робіт, для запобігання травмуванню необхідно:

«- під час переміщення та установки панелей, пультів, запобіжників, сигналізації, телемеханіки, а також шаф і щитків із вторинними апаратами необхідно обв'язувати та зачіплювати обладнання, що переміщується, відповідно до схем стропування вантажів;

- забороняється звільняти вантажопідіймальні механізми до закінчення їх встановлення чи кріплення, а також виконувати кріплення обладнання та окремих його елементів тимчасовими дротяними підвісками;

- забороняється перебувати на елементах конструкції і обладнанні під час їх піднімання та переміщення;

- прилади, шини, проводи та кабелі на висоті більше, ніж 1,3 м, слід встановлювати 3 драбин з поличками (обгородженими поручнями), помостів з огорожею, $з$ телескопічних вишок та гідропідйомників; 
- здійснювати монтаж вторинних мереж необхідно після встановлення та закріплення на конструкції всіх передбачених технічною документацією апаратів, приладів та електрообладнання;

- після передачі змонтованої електроустановки наладчикам виконувати електромонтажні роботи на цій установці без їх дозволу забороняється, а усунення недоробок та дефектів в установках, які передані в налагодження, можна виконувати тільки після їх від’єднання» [2].

Аналіз матеріалів спеціального розслідування нещасних випадків, що сталися через падіння потерпілого з висоті, показав, що потерпілі працівники були допущені до виконання робіт на висоті без проходження спеціального навчання і перевірки знань з охорони праці.

Проаналізувавши виконання робіт на висоті роботодавцю необхідно враховувати наявність наступних небезпечних виробничих чинників: основні (падіння працівника, падіння предметів); супутні (дія електроструму, підвищені рівні запиленості, загазованості повітря, підвищені рівні шуму, вібрації, несприятливий мікроклімат, пожежна небезпека, тощо) [4].

Засоби індивідуального захисту при виконанні електромонтажних робіт є обов'язковими, але можна спостерігати тенденцію 3 боку самих працівників про нехтування правилами їх використання. Проаналізувавши нещасні випадки пов'язані з відсутність 3ІЗ, необхідно навести основні правила їх застосування: робочий одяг не повинен бути занадто вільним, щоб не торкатися частин механізмів, що рухаються; обов'язково використовувати захисні окуляри 3 небитким склом і рукавиці; при необхідності використовувати респіратори і засоби захисту органів слуху; при роботі без зняття напруги в електроустановках напругою до 1000 В або поблизу них необхідні діелектричні калоші.

Щоб уникнути травматизму та покращити умови праці монтажників, роботодавцю необхідно надати всі 3І3, інструкції та неухильно дотримуватись правил охорони праці $[5,6]$.

Для більшого розуміння небезпечності електромонтажних робіт необхідно розгледіти ризики їх утворення, тобто моделювати процеси формування та виникнення травмонебезпечних і аварійних ситуацій

У зображеннях процесів формування виникнення аварій та виробничих травм: «усі випадкові події (явища), що утворюють конкретну аварійну або травмонебезпечну ситуацію, пов'язані між собою причинно-наслідковими зв'язками і діляться на початкові, проміжні та кінцеві події» [7 ].

Початкові дії (небезпечні умови, небезпечні дії) виявляють у процесі обстеження об'єктів виробництва, а проміжні та кінцеві входять до схеми на основі логічного аналізу можливих варіантів перебігу подій.

Слід зауважити, що поняття «початкової дії» введено умовно, бо насправді цим подіям можуть передувати інші. Але вони першими помічаються при обстежені робочих місць та інших об'єктів виробництва.

Причинно-наслідкові зв'язки показано на схемах, що зображують процеси протікання (перебігу) випадкових подій, починаючи з початкових і закінчуючи кінцевими. В результаті нами було одержано логічні моделі процесів, що вивчаються.

Пояснення взаємозв'язків моделі: «кожна логічна модель процесу формування та виникнення небезпечної або аварійної ситуації складається 3 певної кількості випадкових подій, які між собою можуть бути статистично залежними або незалежними. Статистично залежні події - це такі, коли поява наступної події неможлива без виникнення попередньої. Якщо кожна $з$ двох подій, що входять до однісї моделі, можуть з'являтися незалежно одна від одної, то такі події є статистично незалежними. У таких моделях незалежні випадкові події одна відносно одної розміщуються паралельно, а залежні стрілками - послідовно. Причиннонаслідкові зв'язки зображені стрілками, які, крім того, ще показують напрямок протікання (перебігу) подій» [7].

Аналізуючи кожну з побудованих логічних моделей процесів формування та можливого виникнення травмонебезпечних та аварійних ситуацій, ми знаходимо подію, з якої починається небезпечний процес і до виникнення небезпечних наслідків.

Дослідивши логічні зв'язки у зворотному напрямку ми знаходимо ту подію (явище), яка є причиною (однією з причин) формування досліджуваного процесу.

Нижче змодельовані декілька травмонебезпечних ситуацій, які можуть мати місце наприклад на підприємстві при виконанні монтажу протипожежних систем сигналізації.

(C) Федорчук-Мороз В.І., канд. техн. наук, доц., Вісин О.О., канд. істор. наук, доц., Ліщук М.Є. канд. с.-г. наук, доц. 
На (рис. 1.) представлена модель процесу при роботі з ручним електромеханічним абразивним інструментом.

1. Робота з ручним електромеханічним абразивним інструментом (при штробленні бетонної поверхні для прокладання кабелів):

- елетромеханічний інструмент не має захисного кожуха $\mathrm{HУ}_{1}$;

- працівник не використовує 3 ІЗ (окуляри, рукавиці) $\mathrm{HУ}_{2}$;

- при роботі елетромеханічного інструменту руки працюючого знаходиться поряд 3 абразивним кругом інструмента НД;

- При роботі пил та мікрочастинки летять в сторону рук та очей $\mathrm{HC}_{1}$, а це відповідно може призвести до травми рук і (або) очей $\mathrm{HC}_{2}$.

Можливі наслідки - травма, або нещасний випадок.

Міри по усуненню: організувати ефективний контроль при роботі з електромеханічним абразивним інструментом, який повинен мати захисний кожух.

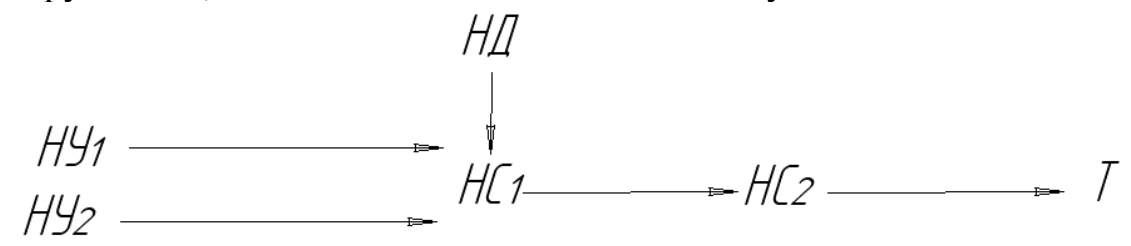

Рис.1. Модель процесу при роботі з ручним електромеханічним абразивним інструментом

2. Робота на висоті при монтажі протипожежної сигналізації (рис.2.):

- при монтажі протипожежної сигналізації не вистарчає драбин $\mathrm{HУ}_{1}$;

- другий монтажник замість драбини використовує інші підручні засоби НД,

- перший монтажник знаходиться на драбина поруч НД;

- перекидання чи поломка підручних засобів замість драбини $\mathrm{HC}_{1}$, $\mathrm{i}$ падіння на першого монтажника $\mathrm{HC}_{2}$.

Можливі наслідки - травма.

Міри по усуненню: закупівля достатньої кількості стійких драбин та перевірити їх на міцність

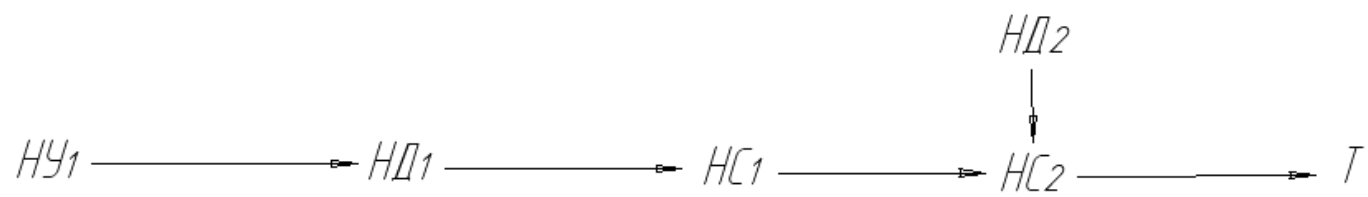

Рис. 2. Модель процесу монтажу протипожежної сигналізації при перебуванні на висоті

3. Монтаж протипожежної сигналізації (рис.3.):

- монтажники не пройшли медичного огляду НУ ${ }_{1}$, i серед них можуть бути хворі $\mathrm{HУ}_{2}$;

- монтажник піднявся на висоту НД;

- втрата монтажником орієнтації внаслідок хвороби (головокружіння, запаморочення, тощо) $\mathrm{HC}_{1}$. Падіння $з$ драбини $\mathrm{HC}_{2}$.

Можливі наслідки - травма.

До роботи на висоті допускаються лише після проходження медогляду.

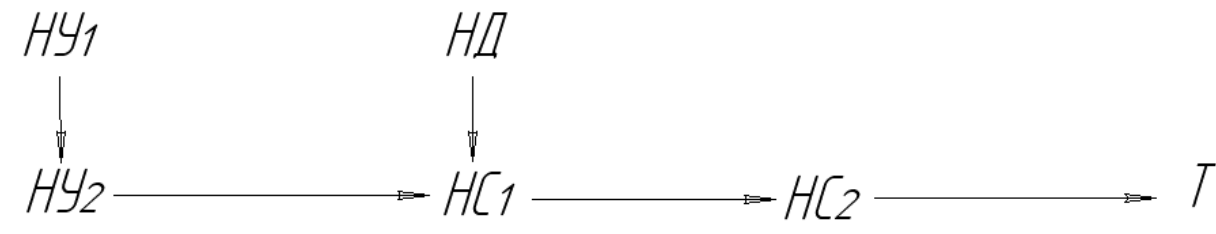

Рис.3. Модель процесу 
Для уникнення можливих травмонебезпечних ситуацій необхідно використовувати засоби індивідуального захисту, обладнання повинно мати запобіжні та захисні короби, забезпечувати монтажників достатньою кількість допоміжних пристосувань, проводити огляд техніки, вчасно проводити медогляди.

Висновки. Проведено аналіз законодавчої та нормативно-правової бази з охорони праці при виконанні електромонтажних робіт, який засвідчив, що особливу увагу необхідно звертати на дотримання правил електробезпеки при виконанні монтажних робіт на об'єктах, а також наявність та справність захисних огороджень. Для досягнення сприятливих та безпечних умов праці необхідно дотримуватись вимог нормативно-правових актів з охорони праці, правил виробничої санітарії, гігієни праці, а також пожежної безпеки. Окрім цього для уникнення травматизму кожен працівник перед приступанням до роботи повинен чітко знати та виконувати правила внутрішнього трудового розпорядку об'єкту який обслуговує, виконувати лише доручену роботу, не порушувати правила охорони праці та пожежної безпеки. Перед початком роботи монтажники повинні знати аварійний вихід, знаходження аптечки та засобів первинного пожежогасіння. Обов'язково користуватися за призначенням спецодягом, спецвзуттям та іншими засобами індивідуального захисту. Якщо є медичні протипоказання, до роботи не приступати, особливо якщо це роботи на висоті. Не допускати до виконання електромонтажних робіт працівників, які мають простудні і хронічні захворювання верхніх дихальних шляхів. Роботодавцю необхідно здійснювати належний нагляд за технічним станом технічних засобів і обладнання, тобто відповідне зберігання та своєчасна заміна спрацьованих деталей згідно вимогам передбаченими технічними умовами заводу-виготовлювача.

\section{Інформаційні джерела}

1. Чорна В.В. Технологія електромонтажних робіт : підручник / В.В. Чорна, С.В. Чорний.- Харків : Компанія СМIT, 2014.- 287 с.

2. Інструкція 3 охорони праці під час монтажу вторинних мереж/ https://dnaop.com/html/31965/doc-instrukcijaz-ohoroni-pracipid-chas-montazhu-vtorinnih-merezh.

3. Про затвердження «Порядку проведення медичних оглядів працівників певних категорій», затверджений наказом МО3 України від 21.05.2007 № 246. Режим постійного доступу: https://www.sop.com.ua/news/ 2536-yak-provoditi-medichniy-oglyad-pratsvnikv-yakvikonuyut-elektromontajn-roboti.

4. Правила охорони праці під час виконання робіт на висоті, наказ Держгірпромнагляду № 62, від 27.03.2007, зареєстрований в Міністерстві Юстиції України 4.06.2007 p. за N 573/13840. Режим постійного доступу: https://zakon.rada.gov.ua/laws/show/z0573-07\#Text.

5. Кодекс законів про працю України від 10.12.71 p. № 322-VIII із змінами i доповненнями. [Електронний ресурс]. - Режим доступу: http://zakon4.rada.gov.ua/laws/show/32208 .

6. Про охорону праці [Електронний ресурс] : закон України від 14.10.1992 р.№ 2694-XII. - Режим доступу: http:// zakon4.rada.gov.ua/laws/show/2694-12.

7. Орел С. М., Мальований М.С. Ризик. Основні поняття: Навчал. посіб. - Львів: Видавництво Національного університету «Львівська політехніка», 2008. - 88 с.

Федорчук-Мороз В.И., канд. техн. наук, доц., Висын Е.А., канд. истор. наук, доц., Лищук М.Е. канд. с.-х. наук, доц.

Луцкий национальный технический университет

\section{ПРАВИЛА БЕЗОПАСНОГО ЭЛЕКТРОМОНТАЖА}

Аннотация. Правила безопасного выполнения электромонтажных работ всегда было актуальным, ведь непосредственно касается сохранению жсизи и здоровья работников. В статье раскрыт вопрос условий труда электромонтажных работ, их безопасное проведение. Особое внимание уделено вопросам успешного $u$ качественного выполнения электромонтажных работ, а также факторам которые приводят $к$ травмам и повреждениям. Проведен анализ выполнения работ на высоте согласно которым предъявлены рекомендации работодателю для учета имеющихся опасных и вредных производственных факторов. Для большего понимания опасности электромонтажных работ были определены

(С Федорчук-Мороз В.І., канд. техн. наук, доц., Вісин О.О., канд. істор. наук, доц., Ліщук М.Є. канд. с.-г. наук, доц. 
риски их образования, то есть моделирование процессов формирования и возникновения травмоопасных и аварийных ситуаций.

Ключевые слова: электромонтажные работы, безопасность, травматизм, правила охраны труда, опасные и вредные факторы.

Fedorchuk-Moroz V.I., Visin O.O., Lishchuk M.E.

Lutsk National Technical University

\section{RULES OF SAFE ELECTRICAL INSTALLATION}

Abstract. The rules of safe electrical work have always been relevant, as they are directly related to saving the lives and health of workers. The article reveals the working conditions of electrical work, their safe conduct. Particular attention is paid to the issues of successful and highquality electrical work, as well as factors that lead to injuries and damage. The analysis of performance of works at height according to which recommendations to the employer for the account of available dangerous and harmful production factors are put forward is carried out. To better understand the dangers of electrical work, the risks of their formation were identified, ie modeling of the processes of formation and occurrence of traumatic and emergency situations.

Keywords: electrical work, safety, injuries, health and safety rules, dangerous and harmful factors. 